\title{
Biodegradation and nutrients removal from greywater by an integrated fixed-film activated sludge (IFAS) in different organic loadings rates
}

\author{
Hadi Eslami ${ }^{1}$, Mohammad Hassan Ehrampoush², Hossein Falahzadeh ${ }^{3}$, Parvaneh Talebi Hematabadi², \\ Rasoul Khosravi ${ }^{4}$, Arash Dalvand ${ }^{2}$, Abbas Esmaeili ${ }^{1}$, Mahmoud Taghavi ${ }^{5}$ and Ali Asghar Ebrahimi ${ }^{*}$
}

\begin{abstract}
In this study, the efficiency of Integrated Fixed-film Activated Sludge (IFAS) system in synthetic greywater treatment and nutrients removal was studied in duration of 105 days according to different Organic Loadings Rates (OLRs). The study was operated in pilot-scale and OLRs of 0.11-1.3 gCOD/L.d. Scanning Electron Microscope (SEM) image showed that the biofilm with a proper thickness was formed on IFAS reactor's media. The results indicated that the best removal efficiency of $\mathrm{BOD}_{5}, \mathrm{COD}$, and TSS were $85.24,92.52$ and $90.21 \%$, respectively, in an organic loading of $0.44 \mathrm{gCOD} / \mathrm{L}$.d. Then, with the OLR increased, the removal efficiencies of $\mathrm{BOD}_{5}, \mathrm{COD}$, and TSS increased as long as the organic loading reached $0.44 \mathrm{gCOD} / \mathrm{L}$.d. But with the OLR increased more, the removal efficiency of these parameters decreased. The ANOVA statistical test results showed that the mean difference of removal efficiency in organic loadings for $\mathrm{BOD}_{5}(\mathrm{p} \leq 0.001)$ and $\mathrm{COD}(\mathrm{p}=0.003)$ was significant, while it was insignificant for TSS $(p=0.23)$. The best removal efficiencies of Total Nitrogen (TN) and Total Phosphorus (TP) were 89.60 and $86.67 \%$, respectively, which were obtained at an OLR of $0.44 \mathrm{gCOD} / \mathrm{L}$.d. By increasing OLR up to $0.44 \mathrm{gCOD} / \mathrm{L}$.d, removal efficiencies of TN and TP increased, while the removal efficiency decreased with the OLR increased more, and this difference was statistically significant $(p=0.021)$. Finally, the results showed that the IFAS system provided a proper efficiency in treatment of the synthetic greywater and it could be used in a full scale.
\end{abstract}

Keywords: Greywater, Biodegradation, Integrated fixed-film activated sludge (IFAS), Removal efficiency, Organic loading rate $(\mathrm{OLR})$

\section{Introduction}

Nowadays, the shortage of water resources, growing population and increasing water demand, inappropriate distribution of water resources, mismanagement of the available water, and climate changes have steered most of the countries toward the research for new water resources (Abdel-Shafy and El-Khateeb 2013; Khosravi et al. 2017; Masi et al. 2010; Shahi et al. 2013). One

\footnotetext{
*Correspondence: ebrahimi20007@gmail.com; ebrahimi20007@ssu.ac.ir ${ }^{2}$ Environmental Science and Technology Research Center, Department of Environmental Health Engineering, Shahid Sadoughi University of Medical Sciences, Yazd, Iran

Full list of author information is available at the end of the article
}

of the ways for compensation of water resources is the reuse of effluent from wastewater (Hourlier et al. 2010), and for the restricted water resources, reuse of domestic wastewater is an important research field in global studies (Ebrahimi et al. 2018; Eslami et al. 2018; Finley et al. 2009).

In general, domestic wastewater includes both greywater and black water (Friedler 2004). The former contains the domestic produced effluent in places, such as the kitchen, showers, baths, wash basins, and laundry. However, the latter is an effluent from toilet (Sanchez et al. 2010). The greywater contains about $70 \%$ of the drinkable water or $60-70 \%$ of the domestic produced 
wastewater (Friedler 2004). Per capita production of greywater is $15-55 \mathrm{~L}$ per person and varies from 90 to $120 \mathrm{~L}$ in a day (Pidou et al. 2007). The greywater specifications are very different depending on the quality of water and type of household activities (Leal et al. 2011). In some studies, the ranges of the various parameters have been reported as follows: $47-466 \mathrm{mg} / \mathrm{L}$ for $\mathrm{BOD}_{5}$, 100-700 mg/L for COD, 25-183 mg/L for suspended solids, and 29-375 NTU for turbidity (Hourlier et al. 2010; $\mathrm{Li}$ et al. 2009). The mean $\mathrm{BOD}_{5} / \mathrm{COD}$ ratio for the greywater has been reported $0.45 \pm 0.13$ which shows its proper biodegradability potential (Leal et al. 2011). Upon separation of greywater from sewage system, the costs associated with wastewater compound collection network can be saved (Hourlier et al. 2010). Moreover, the greywater is less contaminated as compared to the black water and is suitable for reuse (Gross et al. 2007).With proper treatment of the greywater, the effluent can be used for irrigation, flash tank at homes' toilet, and other uses (Abdel-Kader 2013).

The various processes used for the treatment of greywater include natural purification systems, such as wetlands (Gross et al. 2014), physical and biological methods, such as filtration (Katukiza et al. 2014a, b), Rotating Biological Contactors (RBC) (Friedler et al. 2005), Up-flow Anaerobic Sludge Blanket (UASB) (Elmitwalli and Otterpohl 2007), Sequencing Batch Reactors (SBR) (Lamine et al. 2007), Membrane Bioreactors (MBR) (Atasoy et al. 2007; Santasmasas et al. 2013), and other chemical methods (Li et al. 2009; Nolde 2005). An integrated fixed-film activated sludge (IFAS) system is one of the most popular modified activated sludge processes which increases the microbial population and accelerates the biodegradation of organic compounds by adding a fixed media to a suspended growth basin (Kim et al. 2010). This process is actually an integration process which includes the suspended and attached growth and provides the advantages of both attached and suspended growth systems (Mehrdadi et al. 2007). The IFAS process has many advantages in comparison with conventional processes of the activated sludge. This system provides more resistance against organic and hydraulic shock load; besides, it has more flexibility and higher efficacy than other activated sludge processes (Regmi et al. 2011; Rosso et al. 2011). The IFAS system is a good option to upgrade the Activated Sludge System especially in case of facing scarcity of land and provides higher removal efficiency of COD and nutrients relative to conventional activated sludge. It also possesses a lower retention time, higher hydraulic load, and less tank volume (Andreottola et al. 2003; Eslami et al. 2017b). Furthermore, this system is used to increase the removal efficiency of nitrogen and phosphorus as well (Rosso et al. 2011).

Finally, due to drought and lack of water resources in Iran and the importance of separation, treatment, and reuse of greywater, this study aimed to determine the performance of IFAS system in treatment and nutrients removal from the raw greywater.

\section{Materials and methods \\ IFAS pilot plant setup}

Schematic of IFAS process is shown in Fig. 1. IFAS system was composed of transparent Plexiglas sheets with a thickness of $6 \mathrm{~mm}$, an aeration basin, and a sedimentation unit. The aeration basin was rectangular with length, width, and height of 30,20 , and $15 \mathrm{~cm}$, respectively, and was designed with free height of $5 \mathrm{~cm}$ and useful volume of $9 \mathrm{~L}$. The fixed media used in the aeration unit was made of PVC and had honeycomb pattern with a specific surface of $350 \mathrm{~m}^{2} / \mathrm{m}^{3}$ occupying $25 \%$ of the aeration reactor volume. The length, width, and height of the sedimentation unit in IFAS system were $20 \mathrm{~cm}$ at the surface,

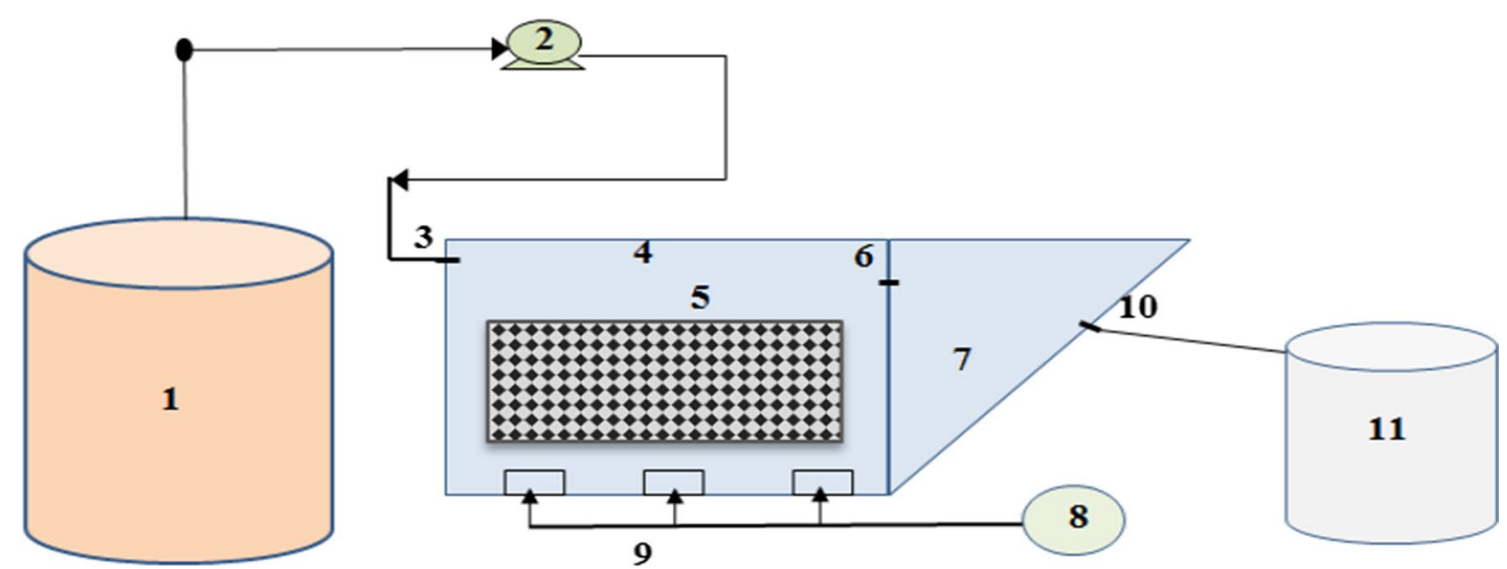

Fig. 1 Scheme of IFAS pilot system (1 Feed tank, 2 injection pumps, 3 input of IFAS aeration reactor, 4 aerated reactor, 5 media, 6 aeration reactor outlet, 7 settling basin, 8 air pump, 9 air inlet pipes, 10 effluent, 11 effluent storage tank) 
$10 \mathrm{~cm}$ at the floor, and $15 \mathrm{~cm}$, respectively. Temperature control was done by a heater aquarium embedded in the aeration basin at $30 \pm 1{ }^{\circ} \mathrm{C}$. Required air for the aeration reactor was supplied thorough pumping of an AIR-8000 air pump with an air flow rate of $9 \mathrm{~L} / \mathrm{min}$ mounted on the floor of the reactor. Feeding the reactors was carried out through picking up greywater from the feed tank by peristaltic pumps (ETATRON Italy) with a flow rate of $20 \mathrm{~L} /$ day. Organic loading rate in IFAS system at 5 loadings was $0.11-1.3 \mathrm{gCOD} / \mathrm{L} . \mathrm{d}$, hydraulic retention time was $10.8 \mathrm{~h}$, and Input COD in 5 OLRs was $50-600 \mathrm{mg} / \mathrm{L}$ according to a previously reported study (Eslami et al. 2017a).

\section{Raw greywater characteristics}

The raw greywater characteristics are shown in Table 1 . The formula for greywater was in accordance with COD $200 \mathrm{mg} / \mathrm{L}$ (Eslami et al. 2017a; Hourlier et al. 2010; Zhu et al. 2014), and also to prepare CODs of 50, 200, 300, 400 , and $600 \mathrm{mg} / \mathrm{L}$, the formula for making greywater was diluted/concentrated according to the mentioned formula.

\section{Seeding and operation of IFAS system}

To set up the system, at first, the input sludge to aerobic digester of the Yazd municipal wastewater plant with the characteristics of Mixed Liquor Suspended Solids $($ MLSS $)=5500 \mathrm{mg} / \mathrm{L}$, Mixed Liquor Volatile Suspended Solids $($ MLVSS $)=4510 \mathrm{mg} / \mathrm{L}$, and the Sludge Volume Index $(\mathrm{SVI})=160 \mathrm{~mL} / \mathrm{gr}$ was used. After 25 days and formation of fixed-biofilm on aeration reactor, firstly the greywater with COD $50 \mathrm{mg} / \mathrm{L}$ and OLR of $0.11 \mathrm{gCOD} /$ L.d was injected into the system, and then different greywater samples with CODs of 100, 200, 400, and $600 \mathrm{mg} / \mathrm{L}$ and OLRs of $0.22,0.44,0.88$, and $1.3 \mathrm{gCOD} / \mathrm{L} . \mathrm{d}$ were logged in IFAS system.

\section{Analysis methods}

In the current study, to determine the pilot efficiency of IFAS in greywater treatment during 105 days, the $\mathrm{BOD}_{5}$, COD, Total Suspended Solids (TSS), Total Nitrogen
(TN), and Total Phosphorous (TP) parameters as well as $\mathrm{pH}, \mathrm{DO}$, temperature, and MLSS were measured. Composite Sampling was done on input and output from the system, and at least five samples were measured for each parameter in each loading. Measurement of the parameters was carried out via diverse methods as follows: COD by dichromate method (closed reflux, 5220 B, colorimetric method, and Spectrophotometer Milton Roy Company 2OD), $\mathrm{BOD}_{5}$ by Winkler method with standard Number of 2510, TSS by spectrophotometry with standard Number of $2540 \mathrm{D}$, total nitrogen (TN) by the Kjeldahl method, total phosphorus (TP) by digestion and Conversion of the various forms of phosphorus to orthophosphate, and determination of the orthophosphate by spectrophotometry. Also, temperature, $\mathrm{pH}$, and DO were measured by portable YSI and MLSS using filter paper of 0.45 micron according to the standard (APHA 2005). Moreover, Scanning Electron Microscopy (SEM) (TESCAN VEGA3, Czech Republic) was used to prepare images from biofilm. In this study, mean and standard deviation of parameters as well as one-way analysis of variance (ANOVA) test were used for comparison of the removal efficiencies at different loadings for each parameter.

\section{Results \\ SEM images}

Figure 2 shows the SEM images before and after biofilm formation on the surface media in the IFAS reactor. As seen, the biofilm after seeding was formed on the media. For sampling of biofilm, samples were dried at first and then transferred to the SEM lab. Table 2 presents the different parameters' specifications in the greywater incoming to IFAS system at diverse OLRs. The mean $\mathrm{pH}$ value was $8.01 \pm 95$ at all organic loadings.

\section{$\mathrm{BOD}_{5}, \mathrm{COD}$ and TSS removal}

Figure 3 shows the output and removal efficiency of $\mathrm{BOD}_{5}$ at different OLRs during the 105 days of the operation. The best removal efficiency of $\mathrm{BOD}_{5}$ was at an OLR of $0.44 \mathrm{gCOD} / \mathrm{L} . \mathrm{d}$ at the rate of $85.24 \pm 3.21 \%$, while

Table 1 Raw greywater formula

\begin{tabular}{llll}
\hline Chemical substance & Amount per liter & Commercial products & Amount per liter (mg) \\
\hline Secondary effluent & $20 \mathrm{~mL}$ & Deodorant & 10 \\
$\mathrm{H}_{3} \mathrm{BO}_{3}$ & $1.4 \mathrm{mg}$ & Shampoo & 720 \\
$\mathrm{C}_{6} \mathrm{H}_{12} \mathrm{O}_{6}$ & $28 \mathrm{mg}$ & Laundry & 150 \\
$\mathrm{Na}_{2} \mathrm{HPO}_{4}$ & $39 \mathrm{mg}$ & Sunscreen or moisturizer & $10-15$ \\
$\mathrm{Na}_{2} \mathrm{SO}_{4}$ & $35 \mathrm{mg}$ & Toothpaste & 32.5 \\
$\mathrm{NaHCO}_{3}$ & $25 \mathrm{mg}$ & Vegetable oil & 7 \\
Clay (unimin) & $50 \mathrm{mg}$ & & \\
\hline
\end{tabular}



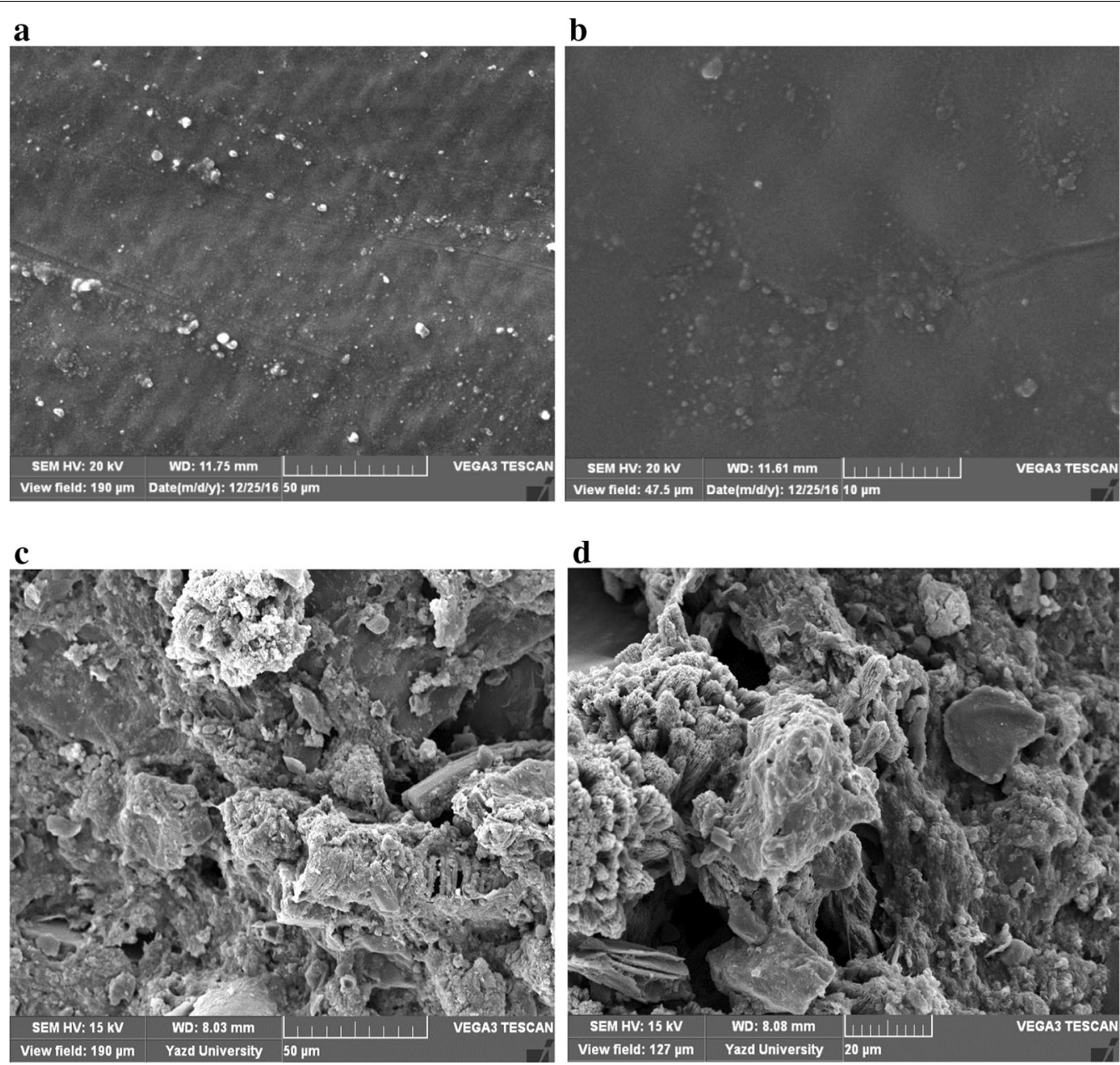

Fig. 2 SEM images from media within IFAS reactor, $(\mathbf{a}, \mathbf{b})$ before biofilm formation, $(\mathbf{c}, \mathbf{d})$ after biofilm formation

Table 2 Mean and standard deviation of $\mathrm{BOD}_{5}, \mathrm{COD}$ and TSS parameters in the greywater incoming to the system with diverse OLRs

\begin{tabular}{lcccr}
\hline Operation time (day) & OLR $(\mathbf{m g C O D} / \mathbf{L} . \mathbf{d})$ & BOD $_{\mathbf{5}}(\mathbf{m g} / \mathbf{L})$ & COD (mg/L) & TSS (mg/L) \\
\hline $25-37$ & 111.11 & $15.43 \pm 3.1$ & $55.23 \pm 7.1$ & $1.11 \pm 1.2$ \\
$38-47$ & 222.2 & $35.52 \pm 8.6$ & $97.33 \pm 8.3$ & $3.37 \pm 1.8$ \\
$48-67$ & 444.4 & $75.34 \pm 9.7$ & $205.12 \pm 10.2$ & $40.21 \pm 3.9$ \\
$68-85$ & 888.8 & $110.48 \pm 10.4$ & $401.44 \pm 12.8$ & $6.13 \pm 8.1$ \\
$86-105$ & 1333.3 & $174.33 \pm 12.1$ & $610.48 \pm 18.2$ & $62.66 \pm 9.5$ \\
\hline
\end{tabular}

the greywater entered into the system with no dilution at this stage. Figure 4 shows the efficiency of IFAS system in terms of COD removal. As it can be seen, the best removal efficiency of COD was $92.52 \pm 4.33 \%$ at an OLR of $0.44 \mathrm{gCOD} / \mathrm{L} . d$. Figure 5 presents the results of IFAS system efficiency for TSS removal from greywater at different OLRs. The best removal of TSS was $90.22 \pm 3.21 \%$ obtained at an OLR of $0.44 \mathrm{gCOD} / \mathrm{L}$.d. ANOVA test results showed that the difference between removal efficiencies in diverse loadings was insignificant $(\mathrm{p}=0.23)$.

\section{Nutrient removal}

In Fig. 6, the mean changes of input and output of TN (Fig. 6a) and TP (Fig. 6b) in IFAS reactor are shown 


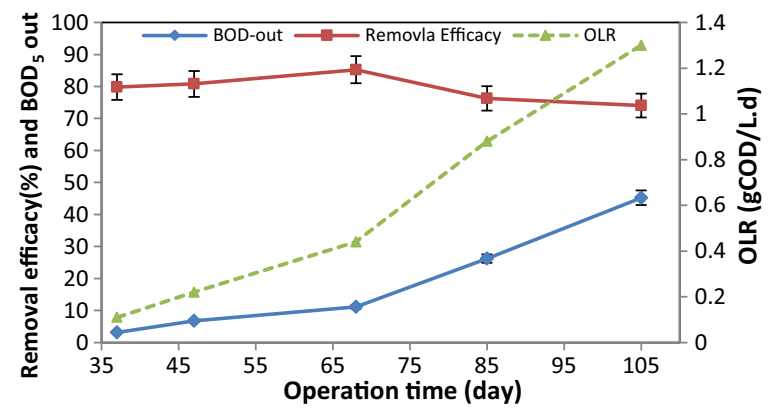

Fig. 3 Mean changes and removal efficiency of $\mathrm{BOD}_{5}$ at different OLRs over the operation time

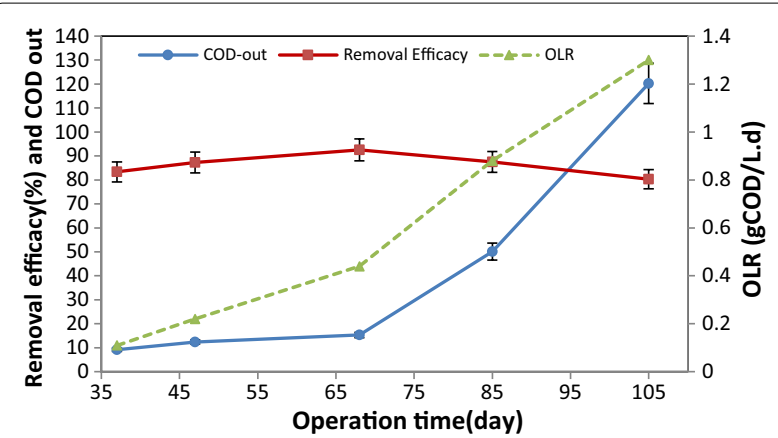

Fig. 4 Removal efficiency and mean changes of COD at different OLRs during their operation time

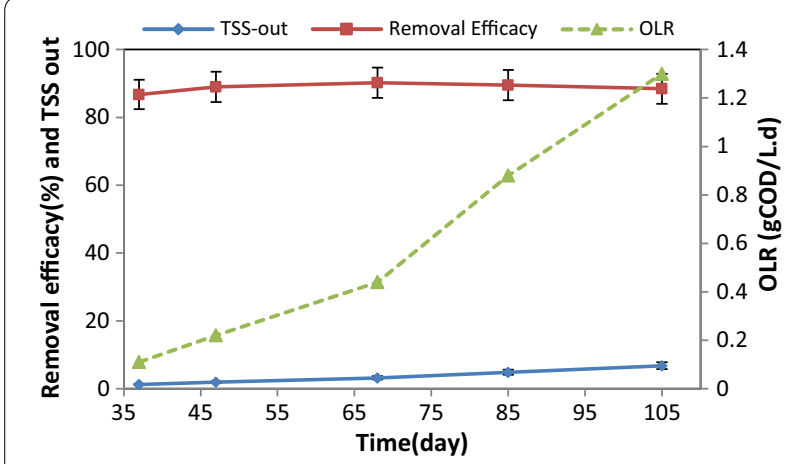

Fig. 5 Mean changes in TSS removal efficiency at different OLRs over the operation

regarding different OLRs, while Fig. $6 \mathrm{c}$ shows the mean removal efficiency. As shown, the best efficiencies of TN and TP were $89.60 \pm 2.41$ and $86.67 \pm 2.14 \%$, respectively, at an OLR of $0.44 \mathrm{gCOD} / \mathrm{L} . \mathrm{d}$. Also, by increasing OLR to $0.44 \mathrm{gCOD} / \mathrm{L} . \mathrm{d}$, removal efficiencies of TN and TP increased, but with the OLR increased more, the removal efficiency decreased. The ANOVA test revealed that the difference between removal efficiencies at diverse OLRs was statistically significant $(\mathrm{p}=0.021)$.

\section{Relationship between the MLSS and OLR}

The mean MLSS changes at different OLRs over the operation are shown in Fig. 7. As depicted, the maximum MLSS was $3900 \mathrm{mg} / \mathrm{L}$ at an OLR of $0.44 \mathrm{gCOD} / \mathrm{L} . \mathrm{d}$.

\section{Discussion}

In the present study, the best removal efficiency of $\mathrm{BOD}_{5}$ was $85.24 \%$. A study by Abdel-Shafy et al. (2014) on greywater treatment using a hybrid system showed that the removal efficiency for $\mathrm{BOD}_{5}$ was $70.6 \%$. Do Couto et al. (2015) studied greywater treatment via anaerobic filter system with UV disinfection. Their results revealed that $\mathrm{BOD}_{5}$ removal efficiency in the output filter was $73 \%$. Saumya et al. (2015) used a constructed wetland system with a Heliconia angusta plant for raw greywater treatment, so removal efficiency of $\mathrm{BOD}_{5}$ was $70 \%$. In a study by Abdel-Kader (2013) on the treatment of greywater by the RBC process and disinfection with UV light, it was shown that the removal efficiency of $\mathrm{BOD}_{5}$ was $93-96 \%$; furthermore, in a study by Hourlier et al. (2010), the $\mathrm{BOD}_{5}$ removal efficiency from synthetic greywater was lower than that in real greywater. Therefore, we could conclude that synthetic greywater had low biodegradability capability as compared to real greywater", and its removal values were lower than those of real greywater. Moreover, aerobic systems showed better performance in the removal of $\mathrm{BOD}_{5}$ from greywater relative to anaerobic systems which might be due to the presence of surfactants in the input greywater and their the negative effects on anaerobic microorganisms (Ghunmi et al. 2010; Hernández Leal et al. 2010). As exhibited in Fig. 2, increase of OLR caused increase of BOD removal which reached its maximum value at an OLR of $0.44 \mathrm{gCOD} / \mathrm{L} . \mathrm{d}$. Next, with the OLR increased more, efficiency decreased. Consequently, ANOVA statistical test results showed a significant difference between the removal efficiencies at different OLRs $(\mathrm{p} \leq 0.001)$. By increasing the contact time of the greywater with microorganisms and allowing longer adaption, the removal efficiency also enhanced. Therefore, by increasing input $\mathrm{BOD}_{5}$ and supplying more organic materials for microorganisms, the removal efficiency soared. But at OLRs of 0.88 and $1.3 \mathrm{gCOD} / \mathrm{L} . \mathrm{d}$, the removal efficiency decreased, so it could be argued that higher levels of $\mathrm{BOD}_{5}$ in greywater, due to the xenobiotic substances, led to decrease of removal efficiency (Jabornig and Favero 2013).

The best removal efficiency of COD was $92.52 \%$, and by increasing OLR in the loadings higher than $0.44 \mathrm{gCOD} /$ L.d, removal efficiency of COD decreased. Increasing the amount of non-biodegradable substances could be related to the effects of increasing the amount of xenobiotic substances in greywater and subsequent reduction of microbial population which reduced the system efficiency at 

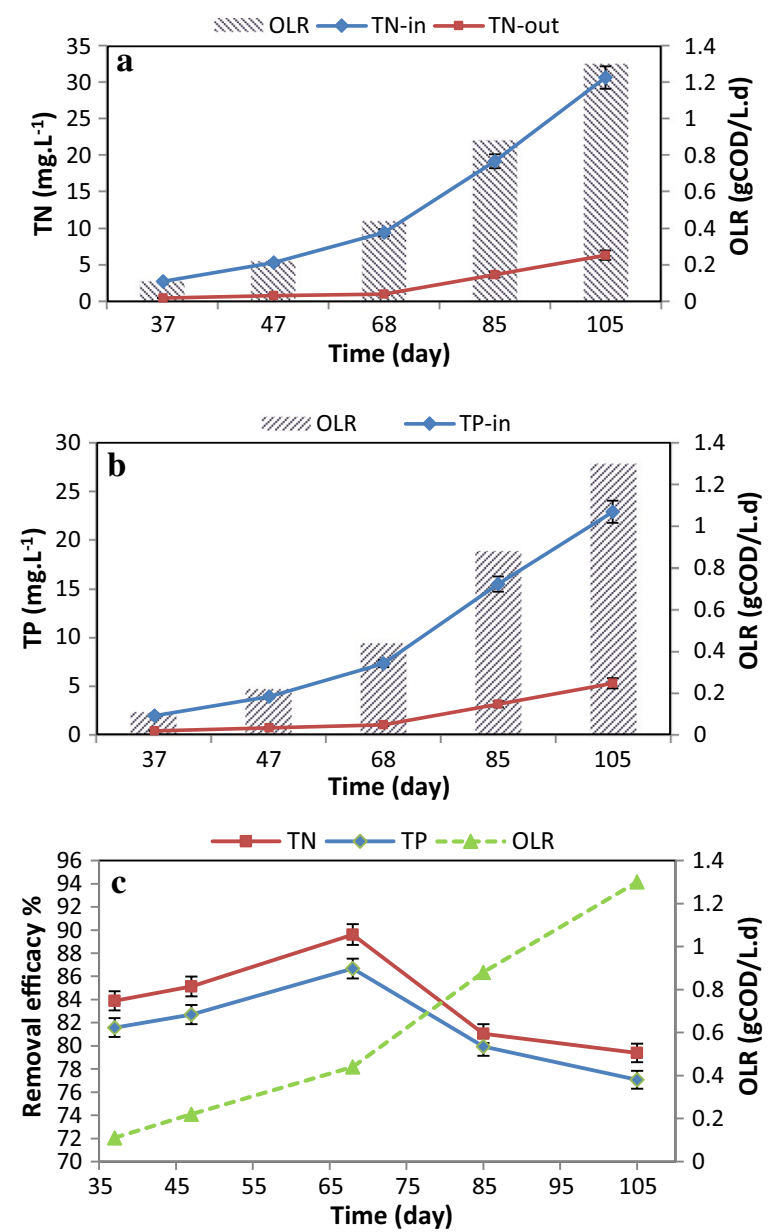

Fig. 6 Mean and standard deviation of TN (a) and TP (b) in the inlet and outlet of IFAS system at different OLRs. c Removal of nutrients at different OLRs

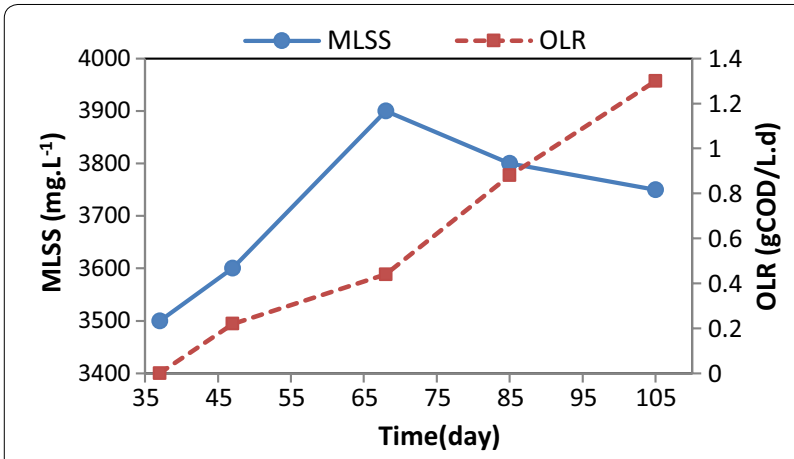

Fig. 7 Mean changes of MLSS at different OLRs over the operation time

high OLRs. Comparing the removal of $\mathrm{BOD}_{5}$ and $\mathrm{COD}$ indicated that the system was more efficient in removal of $\mathrm{COD}$ as compared to $\mathrm{BOD}_{5}$, while the mean removal was higher than that of similar studies with removal efficiencies of 60-80\% (Abdel-Shafy et al. 2014; Friedler et al. 2005; Jabornig and Favero 2013). Comparison of the results showed that the IFAS system had a better performance than other systems due to its integrated system of attached and suspended growth. In fact, a collection of microorganisms with attached and suspended growth could increase the removal efficiency of organic materials (Mahendran et al. 2012). The higher COD removal efficiency relative to $\mathrm{BOD}_{5}$ could be related to the bio sorption, adsorption, and sedimentation of non-biodegradable substances in the greywater on the biofilm and media in IFAS reactor (Eslami et al. 2017a; Nabizadeh et al. 2008).

The best removal efficiency of TSS was $90.22 \%$. In a study by Friedler et al. (2005), the TSS removal efficiency in greywater was $82 \%$. On the other hand, Abdel-Shafy et al. (2014) reported removal efficiency of TSS 70.8\%. Furthermore, in a study by Saumya et al. (2015), the removal efficiency of TSS was $61.65 \%$. Comparing the results of different studies with those of the present study revealed that the IFAS system has had high efficiency in TSS removal which might be due to the fixed media of the biological reactor. Indeed, hybrid systems like IFAS create the conditions of attached and suspended biological growth, and thereby the sludge sedimentation capability improves, so suspended solids along with the sludge are deposited faster with better conditions (Kim et al. 2010). The obtained results were in line with those of Jabornig and Favero (2013) who used Moving Bed Biofilm Membrane Reactor (MBBMR) system for treatment of greywater, while their reported TSS removal efficiency was $98 \%$.

The best removal efficiencies of TN and TP were 89.6 and $86.67 \%$, respectively. Previous studies have showed that IFAS system has a relative efficiency for removal of nutrients from wastewater. Regmi et al. (2011) examined the removal of nitrogen in IFAS system and showed the nitrogen removal in the range of $39-89 \%$. Masterson et al. (2004) investigated the removal of nitrogen in IFAS system and showed the suitability of this system for removal of nutrients since it could reduce nitrogen in the effluent to $5 \mathrm{mg} / \mathrm{L}$. In a study by Zhang et al. (2015), the nitrogen removal efficiency in IFAS system was $80 \%$. Bai et al. (2016) showed that the efficiency of IFAS system for removal of TN and TP was 70 and $81 \%$, respectively. Proper operation of IFAS system for removal of TN can be related to the further growth of nitrification and de-nitrification bacteria on the surface of the biofilm created on media as compared to conventional activated sludge process (Bai et al. 2016; Uddin et al. 2016). Moreover, the suitable phosphorus removal efficiency in IFAS system can be linked to the bacteria in suspension and on the surface of a biofilm which requires phosphorus for its growth (Uddin et al. 2016) or can be related to Phosphorus Accumulating Organisms (PAOs) which mostly tend to have suspended growth (Bai 
et al. 2016). Also, it can be related to the density and the high settling of sludge in IFAS system in comparison with conventional activated sludge process (Kim et al. 2010). In the present study, by increasing OLR to $0.44 \mathrm{gCOD} / \mathrm{L} . \mathrm{d}$, removal efficiencies of TN and TP increased, yet with the OLR increased more, the removal efficiency decreased. Due to the low needed oxygen and the low number of microorganisms at high loadings, nitrification and de-nitrification were limited, and the nitrogen removal decreased. In these conditions, the amount of MLSS and sludge formation also reduced and caused reduction in phosphorus removal (Uddin et al. 2016).

The maximum MLSS occurred at an OLR of $0.44 \mathrm{gCOD} / \mathrm{L} . \mathrm{d}$. According to the best efficiency of $\mathrm{BOD}_{5}$, COD, and TSS at this OLR, it could be concluded that the large population of the bacteria played an important role in greywater treatment. The MLSS was declined by increasing of OLR greater than $0.44 \mathrm{gCOD} / \mathrm{L} . \mathrm{d}$ and COD greater than $200 \mathrm{mg} / \mathrm{L}$. The reason could be the adverse effect of the high amounts of OLR and subsequently the impact of xenobiotic and non-biodegradable compositions on the microbial population which led to abatement of the MLSS (Eriksson et al. 2002; Liberman et al. 2016). Also, as a result of increasing of produced exopolysaccharide (EPSs) in attached growth process, suspended solids in IFAS reactor were precipitated, so MLSS decreased (Schnurr and Allen 2015).

In the present study, the efficiency of IFAS system in synthetic greywater treatment from different organic loadings' rates was studied within a duration of 105 days. SEM image showed that the biofilm was formed on the media of IFAS reactor. The best removal efficiencies of $\mathrm{BOD}_{5}$, COD, and TSS were $85.24,92.52$ and $90.21 \%$, respectively, at an OLR of $0.44 \mathrm{gCOD} / \mathrm{L} . \mathrm{d}$. Then, by increasing the OLR, removal efficiencies of $\mathrm{BOD}_{5}, \mathrm{COD}$, and TSS decreased, and this reduction was statistically significant for $\mathrm{BOD}_{5}$ and COD, while it was insignificant for TSS. The efficiency of the IFAS system in terms of removal of nutrients showed that the best efficiencies of TN and TP were 89.60 and $86.67 \%$, respectively, at an OLR of $0.44 \mathrm{gCOD} / \mathrm{L} . \mathrm{d}$. By increasing the OLR up to $0.44 \mathrm{gCOD} / \mathrm{L} . \mathrm{d}, \mathrm{TN}$ and TP removal efficiencies increased; then, the removal efficiencies decreased with the OLR increasing, and the difference between removal efficiencies in different OLR was statistically significant $(\mathrm{p}=0.021)$. The highest MLSS was $3900 \mathrm{mg} / \mathrm{L}$ at the OLR of $0.44 \mathrm{gCOD} / \mathrm{L} . \mathrm{d}$. The results showed that the IFAS system provides a high efficiency in synthetic greywater treatment.

\section{Abbreviations}

IFAS: integrated fixed-film activated sludge; OLRs: organic loadings rates; SEM: scanning electron microscope; TN: total nitrogen; TP: total phosphorus; NTU: nephelometric turbidity unit; UASB: up-flow anaerobic sludge blanket; RBC: rotating biological contactor; SBR: sequencing batch reactor; MBR: membrane bioreactor; MLSS: mixed liquor suspended solids; MLVSS: mixed liquor volatile suspended solids; SVI: sludge volume index; TSS: total suspended solids; ANOVA: one-way analysis of variance.

\section{Authors' contributions}

All the authors of this paper have collaborated on conducting experiments, analyzing the results, and writing the paper. All authors read and approved the final manuscript.

\section{Author details \\ ${ }^{1}$ Department of Environmental Health Engineering, School of Health, Raf- sanjan University of Medical Science, Rafsanjan, Iran. ${ }^{2}$ Environmental Science and Technology Research Center, Department of Environmental Health Engi- neering, Shahid Sadoughi University of Medical Sciences, Yazd, Iran. ${ }^{3}$ Depart- ment of Biostatistics and Epidemiology, Shahid Sadoughi University of Medical Sciences, Yazd, Iran. ${ }^{4}$ Social Determinants of Health Research Center, Depart- ment of Environmental Health Engineering, School of Health, Birjand Univer- sity of Medical Sciences, Birjand, Iran. ${ }^{5}$ Department of Environmental Health Engineering, Gonabad University of Medical Sciences, Gonabad, Iran.}

\section{Acknowledgements}

The current No. 4217 adopted by the Environmental Science and Technology research center at Shahid Sadoughi University of Medical Sciences in Yazd, and we really appreciate the material and moral supports of this Centre and Vice President of Research at Shahid Sadoughi University of Medical Sciences in Yazd.

\section{Competing interests}

The authors declare that they have no competing interests.

\section{Availability of data and materials}

Most of the data supporting our finding included in the manuscript.

\section{Consent for publication}

Not applicable.

\section{Ethics approval and consent to participate}

The ethical approval conducted in Shahid Sadoughi University of Medical Sciences and Health Services, Yazd, Iran.

Funding

The research was supported by Shahid Sadoughi University of Medical Sciences.

\section{Publisher's Note}

Springer Nature remains neutral with regard to jurisdictional claims in published maps and institutional affiliations.

Received: 12 October 2017 Accepted: 21 December 2017

Published online: 08 January 2018

\section{References}

Abdel-Kader AM (2013) Studying the efficiency of grey water treatment by using rotating biological contactors system. J King Saud Univ Eng Sci 25:89-95

Abdel-Shafy H, El-Khateeb M (2013) Integration of septic tank and constructed wetland for the treatment of wastewater in Egypt. Desalin Water Treat 51:3539-3546

Abdel-Shafy HI, Al-Sulaiman AM, Mansour MS (2014) Greywater treatment via hybrid integrated systems for unrestricted reuse in Egypt. J Water Process Eng 1:101-107

Andreottola G, Foladori P, Gatti G, Nardelli P, Pettena M, Ragazzi M (2003) Upgrading of a small overloaded activated sludge plant using a MBBR system. J Environ Sci Health A 38:2317-2328

APHA (2005) Standard methods for the examination of water and wastewater. American Public Health Association (APHA), Washington 
Atasoy E, Murat S, Baban A, Tiris M (2007) Membrane bioreactor (MBR) treatment of segregated household wastewater for reuse. Clean 35:465-472

Bai Y, Zhang Y, Quan X, Chen S (2016) Nutrient removal performance and microbial characteristics of a full-scale IFAS-EBPR process treating municipal wastewater. Water Sci Technol 73:1261-1268

do Couto EdA, Calijuri ML, Assemany PP, da Fonseca Santiago A, Lopes LS (2015) Greywater treatment in airports using anaerobic filter followed by UV disinfection: an efficient and low cost alternative. J Clean Prod 106:372-379

Ebrahimi A, Hashemi H, Eslami H, Fallahzadeh RA, Khosravi R, Askari R, Ghahramani $E$ (2018) Kinetics of biogas production and chemical oxygen demand removal from compost leachate in an anaerobic migrating blanket reactor. J Environ Manage 206:707-714

Elmitwalli TA, Otterpohl R (2007) Anaerobic biodegradability and treatment of grey water in upflow anaerobic sludge blanket (UASB) reactor. Water Res 41:1379-1387

Eriksson E, Auffarth K, Henze M, Ledin A (2002) Characteristics of grey wastewater. Urban Water 4:85-104

Eslami H, Ehrampoush MH, Ghaneian MT, Mokhtari M, Ebrahimi A (2017a) Effect of Organic Loading Rates on biodegradation of linear alkyl benzene sulfonate, oil and grease in greywater by Integrated Fixed-film Activated Sludge (IFAS). J Environ Manage 193:312-317

Eslami H, Samaei MR, Shahsavani E, Ebrahimi AA (2017b) Biodegradation and fate of linear alkylbenzene sulfonate in integrated fixed-film activated sludge using synthetic media. Desalin Water Treat 92:128-133

Eslami H, Hashemi H, Fallahzadeh RA, Khosravi R, Fard RF, Ebrahimi AA (2018) Effect of organic loading rates on biogas production and anaerobic biodegradation of composting leachate in the anaerobic series bioreactors. Ecol Eng 110:165-171

Finley S, Barrington S, Lyew D (2009) Reuse of domestic greywater for the irrigation of food crops. Water Air Soil Pollut 199:235-245

Friedler E (2004) Quality of individual domestic greywater streams and its implication for on-site treatment and reuse possibilities. Environ Technol 25:997-1008

Friedler E, Kovalio R, Galil N (2005) On-site greywater treatment and reuse in multi-storey buildings. Water Sci Technol 51:187-194

Ghunmi LA, Zeeman G, Fayyad M, van Lier JB (2010) Grey water treatment in a series anaerobic-aerobic system for irrigation. Bioresour Technol 101:41-50

Gross A, Kaplan D, Baker K (2007) Removal of chemical and microbiological contaminants from domestic greywater using a recycled vertical flow bioreactor (RVFB). Ecol Eng 31:107-114

Gross A, Alfiya Y, Sklarz M, Maimon A, Friedler E (2014) Environmental impact of irrigation with greywater treated by recirculating vertical flow constructed wetlands in two climatic regions. Water Sci Technol 69:2452-2459

Hernández Leal L, Temmink H, Zeeman G, Buisman CJ (2010) Comparison of three systems for biological greywater treatment. Water 2:155-169

Hourlier F, Masse A, Jaouen P, Lakel A, Gerente C, Faur C, Le Cloirec P (2010) Formulation of synthetic greywater as an evaluation tool for wastewater recycling technologies. Environ Technol 31:215-223

Jabornig S, Favero E (2013) Single household greywater treatment with a moving bed biofilm membrane reactor (MBBMR). J Membr Sci 446:277-285

Katukiza A, Ronteltap M, Niwagaba C, Kansiime F, Lens P (2014a) A two-step crushed lava rock filter unit for grey water treatment at household level in an urban slum. J Environ Manage 133:258-267

Katukiza A, Ronteltap M, Niwagaba C, Kansiime F, Lens P (2014b) Grey water treatment in urban slums by a filtration system: optimisation of the filtration medium. J Environ Manage 146:131-141

Khosravi R, Eslami H, Almodaresi SA, Heidari M, Fallahzadeh RA, Taghavi M, Khodadadi M, Peirovi R (2017) Use of geographic information system and water quality index to assess groundwater quality for drinking purpose in Birjand City, Iran. Desalin Water Treat 67:74-83

Kim H-s, Gellner JW, Boltz JP, Freudenberg RG, Gunsch CK, Schuler AJ (2010) Effects of integrated fixed film activated sludge media on activated sludge settling in biological nutrient removal systems. Water Res 44:1553-1561
Lamine M, Bousselmi L, Ghrabi A (2007) Biological treatment of grey water using sequencing batch reactor. Desalination 215:127-132

Leal LH, Temmink H, Zeeman G, Buisman C (2011) Characterization and anaerobic biodegradability of grey water. Desalination 270:111-115

Li F, Wichmann K, Otterpohl R (2009) Review of the technological approaches for grey water treatment and reuses. Sci Total Environ 407:3439-3449

Liberman N, Shandalov S, Forgacs C, Oron G, Brenner A (2016) Use of MBR to sustain active biomass for treatment of low organic load grey water. Clean Technol Envir 18:1219-1224

Mahendran B, Lishman L, Liss SN (2012) Structural, physicochemical and microbial properties of flocs and biofilms in integrated fixed-film activated sludge (IFFAS) systems. Water Res 46:5085-5101

Masi F, El Hamouri B, Shafi A, Baban A, Ghrabi A, Regelsberger M (2010) Treatment of segregated black/grey domestic wastewater using constructed wetlands in the Mediterranean basin: the zer0-m experience. Water Sci Technol 61:97-105

Masterson T, Federico J, Hedman G, Duerr S (2004) Upgrading for total nitrogen removal with a porous media IFAS system. Proc Water Environ Fed 2004:307-323

Mehrdadi N, Azimi A, Bidhendi GN, Hooshyari B (2007) Determination of design criteria of an H-IFAS reactor in comparison with an extended aeration activated sludge process

Nabizadeh R, Naddafi K, Mesdaghinia A, Nafez AH (2008) Feasibility study of organic matter and Ammonium removal using loofa sponge as a supporting medium in an aerated submerged fixed-film reactor (ASFFR). Electron J Biotechnol 11:6-7

Nolde E (2005) Greywater recycling systems in Germany results, experiences and guidelines. Water Sci Technol 51:203-210

Pidou M, Memon FA, Stephenson T, Jefferson B, Jeffrey P (2007) Greywater recycling: a review of treatment options and applications. Proc Inst Civ Eng 160:119-131

Regmi P, Thomas W, Schafran G, Bott C, Rutherford B, Waltrip D (2011) Nitrogen removal assessment through nitrification rates and media biofilm accumulation in an IFAS process demonstration study. Water Res 45:6699-6708

Rosso D, Lothman SE, Jeung MK, Pitt P, Gellner WJ, Stone AL, Howard D (2011) Oxygen transfer and uptake, nutrient removal, and energy footprint of parallel full-scale IFAS and activated sludge processes. Water Res 45:5987-5996

Sanchez M, Rivero M, Ortiz I (2010) Photocatalytic oxidation of grey water over titanium dioxide suspensions. Desalination 262:141-146

Santasmasas C, Rovira M, Clarens F, Valderrama C (2013) Grey water reclamation by decentralized MBR prototype. Res Conserv Recycl 72:102-107

Saumya S, Akansha S, Rinaldo J, Jayasri M, Suthindhiran K (2015) Construction and evaluation of prototype subsurface flow wetland planted with Heliconia angusta for the treatment of synthetic greywater. J Clean Prod 91:235-240

Schnurr PJ, Allen DG (2015) Factors affecting algae biofilm growth and lipid production: a review. Renew Sustain Energy Rev 52:418-429

Shahi DH, Eslami H, Ehrampoosh MH, Ebrahimi A, Ghaneian MT, Ayatollah S, Mozayan MR (2013) Comparing the efficiency of Cyperus alternifolius and Phragmites australis in municipal wastewater treatment by subsurface constructed wetland. Pak J Biol Sci 16:379-384

Uddin SMN, Li Z, Adamowski JF, Ulbrich T, Mang H-P, Ryndin R, Norvanchig J, Lapegue J, Wriege-Bechthold A, Cheng S (2016) Feasibility of a'greenhouse system'for household greywater treatment in nomadic-cultured communities in peri-urban Ger areas of Ulaanbaatar, Mongolia: an approach to reduce greywater-borne hazards and vulnerability. J Clean Prod 114:431-442

Zhang L, Liu M, Zhang S, Yang Y, Peng Y (2015) Integrated fixed-biofilm activated sludge reactor as a powerful tool to enrich anammox biofilm and granular sludge. Chemosphere 140:114-118

Zhu S-N, Wang C, Yip AC, Tsang DC (2014): Highly effective degradation of sodium dodecylbenzene sulphonate and synthetic greywater by Fentonlike reaction over zerovalent iron-based catalyst. Environ. Technol 1-27 